
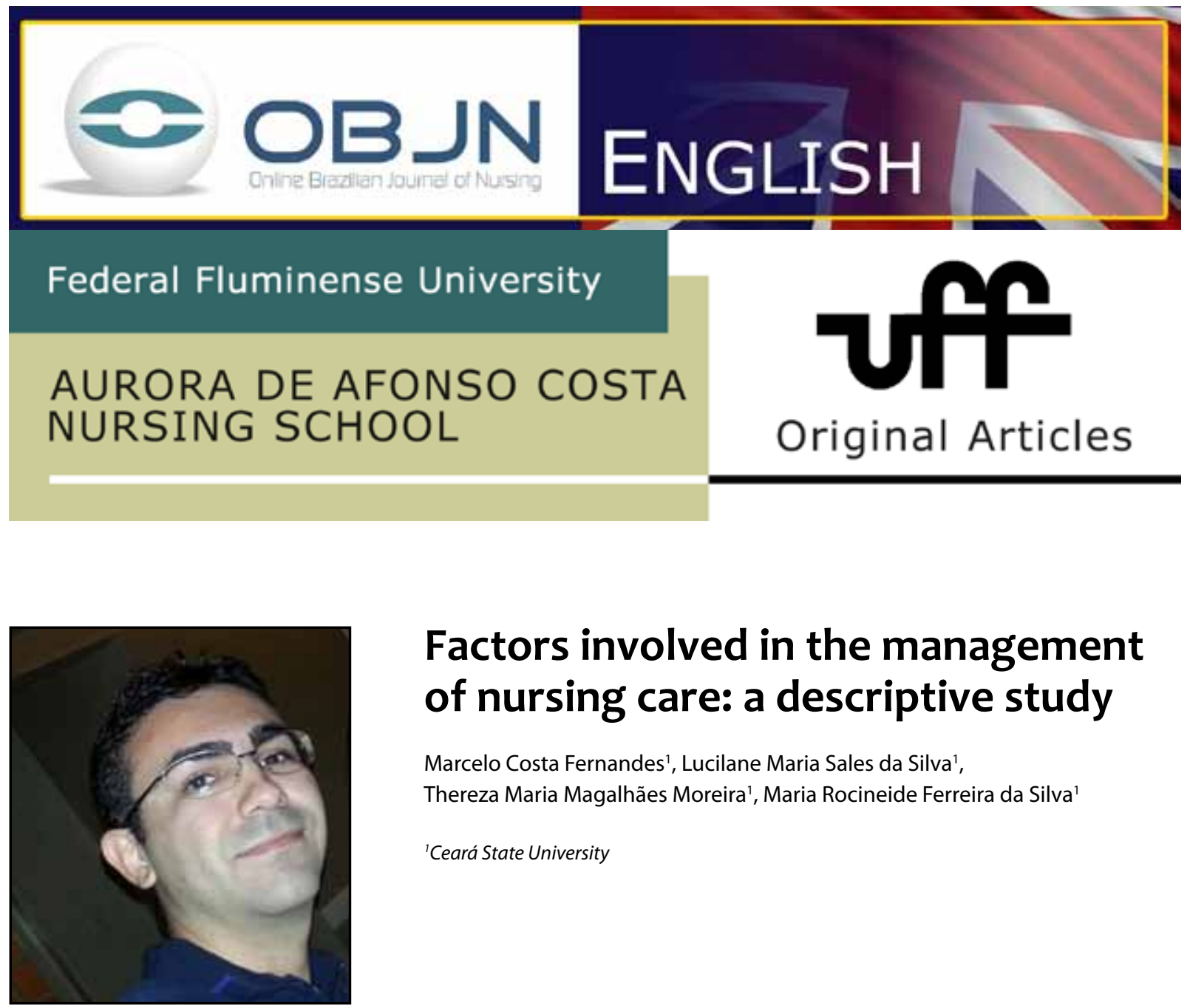

\title{
Factors involved in the management of nursing care: a descriptive study
}

\author{
Marcelo Costa Fernandes' ${ }^{1}$ Lucilane Maria Sales da Silva', \\ Thereza Maria Magalhães Moreira', Maria Rocineide Ferreira da Silva' \\ ${ }^{1}$ Ceará State University
}

\begin{abstract}
Aim: To investigate the factors involved in care management.

Method: This is a descriptive study, performed with 32 nurses from Basic Care units in Maracanaú, Brazil, from May to July 2012. The methodological process used was the Discourse of the Collective Subject, to order and organize the data.

Results: The most important concerns were: excessive demand, resistance of the users to the proposed activities in health prevention and promotion and precarious organizational structure. The facilities presented were: support from the health department, teamwork and autonomy of the nurse.

Discussion: The difficulties experienced generated a gap between the caring service and the managerial process, especially those linked to the instability of the work processes and the traditional assisting model, but on the other hand, the teamwork, the support of management and autonomy stimulated the interaction between caring and managing. Conclusion: The Attention Care Service presents ambivalences because sometimes it permits and at other times it separates caring and care management.
\end{abstract}

Descriptors: Public Health Nursing; Nursing Care, Management. 


\section{INTRODUCTION}

The management of nursing care is understood to be a dialectical relationship between the work processes of caring and management. In other words, it is when there is an articulation between the knowledge of management (indirect care roles) and of caring (direct care roles), permitting the existence of a certain interface between these two objects in the professional practice of the nurse, whose objective is to generate a systematized and quality care to the users of nursing services ${ }^{(1)}$.

Among the countless locations of health assistance where the nurse can develop the roles of care management the Strategy in Family Health units (ESF, in Portuguese) is notable. This was developed based on the Brazilian National Policy in Basic Care (PNAB, in Portuguese), as an essential strategy to expand and consolidate this level of care throughout the country ${ }^{(2)}$.

In ESF it is noted that the process of the nurse's work has two complementary sides: caring and management. On the first side, the nurse considers as the main object, the intervention and the needs in nursing care, and aims to provide a holistic and quality caring service. On the second side, the nurse visualizes the principal object to be the organization of work and the nursing agents, aiming to develop and implement adequate conditions of nursing care for the users, and of performance to the other laborers ${ }^{(3)}$.

Therefore, the nurse exercises care management in the ESF by developing his best professional practice, and as a consequence, the holistic capacity of his roles. Furthermore, these roles empower his work, which enables a good flow of tasks to be done, as well as overcome assistive practices, the transcendence of the simplified mode of thinking, and the promotion of nursing care as a product of multiple social interactions ${ }^{(4-5)}$.
While considering that caring is the symbol and the nucleus of the work process of nursing, the conclusion can be drawn that the objective of management roles of the nurse should be the quality of nursing care. Therefore, the division between the caring and managerial roles only harms the potential quality, and generates conflicts in the work routines of the nurse, either from the professional with his own routine, or the relationship between the nursing team and the health team ${ }^{(6)}$.

In view of this, the following guiding question arises: what are the factors involved in the management of nursing care in the ESF?

We must mention that this study is fundamental to consolidate a topic which has not been greatly studied in Brazil, meaning that there are many gaps in the understanding of the management of nursing care at this level of healthcare. Therefore, this present research aims to investigate the factors involved in the performance of the management of caring roles by the nurse in ESF.

\section{METHOD}

This is a descriptive study, with a qualitative approach, performed with 32 nurses from ESF in the municipality of Maracanaú, Brazil. Today, the city has 51 teams in Family Health, which are part of Fortaleza Macroregion (which is the state capital), and also the $3^{\text {rd }}$ Health Microregion of the State (also known as $3^{\text {rd }}$ Health Regional Coordination or CRES, in Portuguese). The chosen data collection technique was the semi-structured interview. These interviews took place from May to July 2012 in a reserved place at the Basic Care Unit. The criteria adopted for inclusion were to have worked more than twelve months at the health unit which was considered to be enough time for the professional to 
become familiar with the dynamics of ESF. The criteria for exclusion were: to be on vacation, sick leave or suspended. The collection of data ended when the theoretical saturation was achieved.

The methodological process known as Discourse of the Collective Subject (DCS) was used to order and organize the empiric data produced by the semi-structured interviews. This is a tool that enables the representation of the thinking of a certain group. It is a methodological proposal that suggests the sum of ideas not by a numerical system, but by the expression of the collective thinking through the discourse being operationalized in a methodological format ${ }^{(7)}$.

DCS basically analyzes the material constructed by a collectivity through the review of interviews, and after that, extracts the central ideas $(\mathrm{Cl})$ and its main key-expressions $(\mathrm{KE})$. Then, the content of the answers that have similar content is grouped in discourse-synthesis rewritten in the first person of the singular ${ }^{(7)}$.

$\mathrm{Cl}$ is the linguistic expression that shows and describes more synthetically and precisely each one of the discourses analyzed. The KE can be defined as fragments, sections or literal transcriptions of the discourse ${ }^{(7)}$. In this research, the $\mathrm{Cl}$ and their respective $\mathrm{KE}$ will be presented, identified by a corresponding numbering, and after that, they will be discussed based on scientific literature.

The research started after approval by the Ethics in Research Committee of Ceará State University under protocol number 26907. The ethical and legal components are present in all stages of this research according to the Resolution 466/12 of the Brazilian National Health Council.

\section{RESULTS}

Of the 32 nurses that participated as subjects of this study the majority were female $(n=30)$; from the age group from 26 to 30 years old $(n=13)$; and all of them had finished their undergraduate studies no more than five years ago. There was a significant joviality of the participants of this study, seen both by their recently finished undergraduate studies, and by the age of the subjects.

With regard to the context of the roles performed by these nurses, it was noted that there were difficulties and facilitating factors that interfered in the process of care management in ESF. Therefore, the $\mathrm{Cl}$, and their respective $\mathrm{KE}$, extracted from the reports of the nurses will be presented.

Major obstacles to the performance of care management in ESF

With regards to the major obstacles there are three $\mathrm{Cl}$ which demonstrate the difficulties the nurses find in care management in ESF.

The first $\mathrm{Cl}$, which deals with excessive demands of the users attended in the unit, was generated based on the interview of 12 nurses:

$\mathrm{Cl}$ 01: Excessive demand of users attended in the unit

KE 01: I have a very excessive demand; sometimes I support a population above the number expected. There are days when I take care of fifteen, sixteen people in one morning; it's a lot of people. This happens because of a great number of families, almost two thousand, and the large number of users ascribed to my area. Then, this huge demand searches for the unit, sometimes delaying some of my other duties, as I needed to be with my own team, organizing and planning the routines that could reflect on the assistance to this community, like in a street with lots of cases of dengue fever 
and that we could intervene, however we end up not being able to leave the unit to perform these actions. Then, I could work better, calmer, to have more time to talk with the patient, but in fact, because of the demand, I end up speeding up my consultations and losing the quality of my work. And another thing that contributes to this great amount of caring service is the lack of medical professionals in my team. I become overloaded, and I have to take care of more users, work for two and consequently, some of the duties I leave undone, like working in groups of users. This creates an extra burden to my work.

The second $\mathrm{Cl}$ was built from the reports of the nurses regarding the curativistic model, and the resistance to the roles of prevention and promotion by the users of ESF. The respective KE of this $\mathrm{Cl}$ as generated by nine interviews:

\section{$\mathrm{Cl}$ 02: Curativistic view and resistance to the preventive and promotional activities by the users of ESF}

KE 02: What impedes the performance of many activities here in the unit is the idea shared by the users that the public clinic works to heal people; they are not worried about a holistic care, especially related to the activities of disease prevention and promotion of health that we develop here. I see that the reality here in this unit is that usually the users only want some medication, they must leave with a prescription for a drug to heal their illness - they are addicted to this condition. And there are some users that only come to renew their prescriptions. Another difficulty is the lack of cooperation by the users, because when I mention that I am going to perform an activity in education in health, they don't want to know about it, they get angry, mention that they're going home, to fix dinner; they don't see the importance of these activities in health, affirming that you are not working and that our work is to be in the office only, attending and prescribing medications, I also have some difficulty to get the patients to be part of a group, as there are many users who are bearers of chronic diseases, and then I could work with them to prevent the complications. Even though, I have a group, however on the days scheduled there is no one, or one or two come by, and then I cannot continue with the activity.

Ten nurses participated in the construction of the KE of the third $\mathrm{Cl}$. They mentioned the precarious organizational structure of the unit as a factor which impeded the performance of care management, which will be detailed in the following KE:

\section{Cl 03: Precarious organizational structure of the health facility}

KE 03: One thing that stresses me is the problem related to the physical structure of the unit, because it is really bad. This is a rented building, and it has been a while since we are here and it is all really dangerous. They had to adapt this room, for example, so I could attend the patients, because there was no other room available. We work improvising everything, and when it rains, there is not a good spot to work in this place. When the people from the Supporting Nucleus for Family Health (NASF, in Portuguese) come here to take care of the users, they don't have any room to stay and use, like, for example, the occu- 
pational therapist, the physiotherapist, the psychologist and the social worker try to do an individualized work, but there is not a specific room for them, and they end up working in the corridors. Sometimes I lend my room for a certain, specific consultation. When I do something about education in health, like creating groups or running lectures, I don't have a place, such as a meeting room or an auditorium that I could perform these activities. Here there is a corridor, which is the place that I do my activities of education in health, but it's really difficult to do so, because while I am trying to talk about a topic to the group, other users that are going to medical consultation that have to go through that same corridor, then it takes away the concentration and the line of thought of the participants of the group. Then what I see is this issue of the physical structure, which is really a low point and it ends up creating an extra difficulty to my activities. Another issue would be the lack of a vehicle. Sometimes we are out of vehicles. Last week I was without a vehicle to take me to my visits. Without it, the caring that you planned for the home visits are compromised, once they will not occur and the ones who feel the harmful effects are the ones staying in bed, which will develop into a delay of the vaccines to the elderly that are not able to make it to the clinic.

\section{Major facilitating factors to the performance of care management in ESF}

Among the factors intervening in the performance of the activities in nursing care management in ESF there are the facilitating factors. In this research three $\mathrm{Cl}$ were identified and built which deal with the idea of facilitating.
The fourth $\mathrm{Cl}$, about the support from the local health department, was created by the analysis of the interviews of 21 nurses, which will be discussed below, followed by its own KE:

\section{KE 04: Support from the local health depart- ment}

KE 05: one of the factors that I see that most of the times facilitates my job is the partnership we have with the local health department, especially with the attention care coordination. The support from the local health department really helped us during our activities. Today's management believes in cooperation, in the opening, in listening to our demands and searching for solutions. I see the responsible work of the health department in providing instruments, materials and even professionals to contribute in some groups of education in health that I am developing here. The local health department has constant educational programs for the professionals, such as courses and workshops, which help to renew our understanding regarding our procedures, because they always try to use new teaching methodologies, such as permanent education, and I see that it is reflecting in my practice. I see that these educational activities that the health department does for us are fundamental because there are always new treatments, new caring techniques to know, and it is fundamental to recycle our knowledge. Another thing that really facilitates our work here in this city is the presence of a coordinator to each health unit, and one manager to each Health Vigilance Area [AVISA, in Portuguese], which were created by the health department. The coordinator and the manager help me a lot during my 
work in Basic Care. They are here, on a daily basis, watching out to check if we need anything to perform our daily caring roles, such as materials, and also structural and organizational things, broken equipment that needs substitution, if there is the necessity to repaint the walls, substitution and relocation of professionals during annual leave, missing cleaning material that needs to be bought, and even the supply of medication of the unit's pharmacy. The presence of the coordinator in the unit, and of the AVISA manager, helps a lot, as in many cities, it is the nurse's responsibility to take care of all that.

The fifth $\mathrm{Cl}$ deals with the teamwork experience, as a facilitator to performance of caring management. The interviews with 17 nurses were used to build the following KE:

\section{Cl 05: Teamwork}

KE 05: I see that teamwork is a facilitator to my role as a nurse. I usually say that this health unit is a big family, because we have a strong partnership among all of its members. Teamwork in a health unit is fundamental, because if for some reason I cannot make it to work, the nurse of the other team can take care of my users, and if she misses a day, I can take care of hers. When we are designing a group to work in education in health, all teams participate. Then we work as a team to develop the activities well and to share the responsibilities. Another important factor is the presence of the NASF, who came to add up to our team. I can also send a user to have an evaluation with the phonoaudiologist, psychologist, occupational therapist and social worker when I see that the user needs an intervention from another professional. I want to add the partnership we have with the Health Community Agents [ACS, in Portuguese], because they have a very important role in the performance of my roles. The ACS are the connection between the health unit and the community; they transmit all the information from the population to us in the unit, and also our information to the community. Therefore, integrated teamwork helps me in my roles as a professional.

The last $\mathrm{Cl}$, about the facilities to perform the actions in care management, deals with the autonomy of the nurse in Basic Care. The following KE was built from the interviews with four nurses:

\section{Cl 06: Autonomy of the nursing professional to work in ESF}




\section{DISCUSSION}

KE 01 reports, according to the nurses, excessive demand from the users receiving daily care in the ESF. However, according to the Ordinance 2,488 from October 21, 2011 of the Brazilian National Policy in Basic Care, each family health team must be responsible for no more than 4,000 users, with a recommended average number of 3,000 users; it also establishes criteria of equity to define the best number. This same Ordinance also recommends that the number of users per team must take into consideration the level of vulnerability of the families in the team's territory, which means that higher the level of vulnerability, the fewer the number of users per team ${ }^{(8)}$.

Even with a limit of users established by the Brazilian Ministry of Health, the amount of families supported by the ESF in this municipality is well above the limit established by the PNAB, according to the reports seen on KE 01 of the nurses, a fact also observed in other parts of Brazil(9).

Within this context, the nurse is distanced from care management, as the activities related to indirect care, such as planning, coordination and organization, are not performed due to the excess of users that need clinical care.

It was also seen in KE 01, that there is some uneasiness from the nurses with regards to the lack of some members in the team, especially due to the absence of medical professionals, which is reflected in the intensity of their work. This fact alone makes the nurse include in the nursing care the scheduled users who were going to have a consultation with the doctor. This reduces the quality of the service provided, which originates from the large demand and reduces the time for each consultation; the roles of welcoming, creating a bond and listening are not performed anymore.
The lack of doctors in ESF is a result of the work schedule and of payment. Many city halls do not have public tenders to hire more new doctors, which then generates a series of precarious work contracts with a large difference in salary or wages among the nearby municipalities. This will then create a high rotation of professionals, as the doctors prefer to migrate from city to city based on the financial compensation they will receive ${ }^{(10)}$.

According to the nurses' KE 02 one of the obstacles experienced by these professionals in ESF while performing their roles in care management is the resistance that the users impose, especially to the activities of illness prevention and health promotion. This opposition reflects a historical process that created models of healthcare, mainly the biomedical model centered in the clinical conception of the physiopathology, which neglects other determining aspects of the illness-health process, such as cultural, political and economical issues involved in this process. Such a traditional assisting paradigm is still present in the health services in Brazil(11).

Thus, this traditional model of health assistance influenced and is still influencing both the health professionals and the users of Basic Care, as was seen in KE 02. This model of individualistic approach directs its actions towards the subjects who are ill, incorporating all the cultural practices and understandings, reproduced in Basic Care ${ }^{(12)}$.

Consequently, it is is necessary to separate the traditional model in ESF, as these fragmented and vertically integrated practices are focused on the disease, which has a fast and practical resolution. This means that it is only based on medication therapy, directing the users to an erroneous understanding with regard to the resolution of their health problems, which also demonstrates the influence of the process of medicalization in assisting routines. 
We also see in the KE 02 the difficulty experienced by the nurses in the management of health groups with the users, as there is little adherence and participation in these activities. In this context, it is fundamental that the nurse finds partnerships with other members of the health team, with the objective of educating the users about the importance of educational activities and, as a consequence, to increase the adherence of the users to these educational activities.

However, it is believed that this understanding by the users will only be achieved from the moment the nurse sees the importance of this social factor in the process of the construction of caring activities. In other words, when the user is empowered to perform his own self-care, and when these actions are in accordance with the user's real needs. Therefore, the educational activities are not the nurse's unilateral construction, but are also provoked by the needs of the user.

Hence, from the moment the interaction between the nurse and the user occurs, both the activities of indirect care and the direct care will be performed in a more democratic way. As a result care management will be done with more efficiency and effectiveness.

KE 03 deals with the limitations of the physical space of the health unit. This is based on the manual of physical structure of Basic Health Units, as these units must have a specific area to be used for meetings where the activities of health education can take place. This is contradictory to the discourse the nurses presented in this research ${ }^{(13)}$.

What is expected from the physical structure of a location that serves as a Basic Care Unit is that it does not have to be perfect or standardized, but that it can hold in one single space all the organizational, managerial and community needs ${ }^{(14)}$. It is based on this adequate physical space that the nurse will find adequate conditions in which to perform the activities of care management.

On the other hand, what is seen around the Brazilian national network of Basic Care are health units that are in precarious state of conservation and hygiene, with infiltration on the walls and deficient lightning observed, besides the fact that many ESF are located in physical structures that were not built for this use $\mathrm{e}^{(15)}$

Yet, according to the nurses' KE 03, there is information about the lack of a specific space for NASF professionals to perform their activities. It is the local health department's responsibility to provide the adequate physical space in health units, and also to guarantee the expense resources needed to develop the minimal roles described in the job description of the many professionals that compose the NASF team. Furthermore, a specific physical structure for the visiting NASF team is not recommended ${ }^{(8)}$.

The precarious physical structure is really a problematic factor, but it does not completely impede care management, especially with regards to the activities of health education, such as groups. Nurses can use other social buildings present in their ascribed territory, such as churches, squares and schools, to perform such actions, which can lead to a greater interaction with the community itself.

It was also seen in KE 03 that the lack of a vehicle was a factor impeding the performance of the nurse's care management, as the work model in Basic Care foresees the professional working in the community will generate many activities, such as home visits and educational activities. These actions are limited once the nurse does not have reliable transportation available to leave the unit to perform such roles.

The support from the local health department, especially in regards to the supply of material resources, was mentioned in the nurses' $\mathrm{KE}$ 04. The directives and standards of the ordinance 
of Basic Care determines that the local health departments must guarantee enough resources, equipment and materials to enable the functioning of health units, and the performance of the complete set of proposed roles ${ }^{(8)}$.

With this support, the nurse will have the conditions to prevent and provide resources, which will permit the continuity of the plan of actions and the interface between the process of work in caring and managing, or in other words, the performance of care management ${ }^{(16)}$.

Another point highlighted in KE 04 is the constant use of educational activities for the health team done by the department's administration. This is also a sign that the local health department is following the ordinance of Basic Care, because it is this department's responsibility to create actions and enable institutions to improve and guarantee the permanent education of ESF professionals ${ }^{(7)}$.

Therefore, it is essential that these instructions are based on the health needs of the people and the population, aiming to transform professional practices and work organization. The performance of work processes in respect of nurse care management will be done with more efficiency and effectiveness ${ }^{(17)}$.

Notwithstanding, it is important to mention that these findings diverge from other research in Brazil as a whole, where there are frequent interruptions in the education of the professionals in Basic Care, and in the permanent educational processes in the area in which these professionals work ${ }^{(18)}$.

In this research, with regards to municipality, the health units were divided by Health Vigilance Areas (AVISA, in Portuguese). Each AVISA was under the responsibility of one manager, who had three to six health units, and then each unit would have an administrative coordinator, the person responsible for guiding local activities.
The presence of an AVISA manager and of the unit's coordinator is fundamental to the nurse, according to KE 04. As in many other municipalities, the nurse is the one responsible for the administrative activities and the management of the unit, besides representing the link between the ESF and the local health department ${ }^{(19)}$.

Therefore, with the presence of an AVISA manager and the unit's coordinator, there is a reduction in the excess roles performed by the nurse, facilitating this professional to dedicate more time to the his professional roles, and among those, the actions related to care management.

It is necessary to point out, as seen in the nurses' KE 05, the importance of teamwork for the teams in ESF. The presence of different professional backgrounds, as well as the high level of interaction among them, is essential to the point that not only are the roles shared, but also that they have a place to develop an interdisciplinary process in which gradually the nuclei of specific professional competencies enrich the common grounds of professional competencies, and thus amplify the caring capacity of the whole ESF team ${ }^{(8)}$.

Yet, according to KE 05 of the nurses, what really helps to achieve a certain level of integrality in care, and the interdisciplinarity of the roles, is the existence of NASF teams and the partnership with the ACS.

On that basis, it can be concluded that teamwork facilitates above all, the interaction between NASF and ACS professionals, contributing to articulation of caring and management. Once the nurse can use the managerial tools and instruments, such as planning, evaluation, coordination and task delegation, more efficiently this will generate the correct performance of work processes in care management ${ }^{(1)}$.

In KE 06, the nurses discussed autonomy, which they mentioned having when performing 
the activities in the ESF, and stated that it is a factor that contributes to performance of care management.

The nurse gets more space, autonomy and decision-making power in the team through his effective presence in the ESF, leaving behind the status of being a complement and an instrument of medical work, to become part of the collective work in health services, co-responsible in the construction of health services, adding his nursing understanding and practices related to the social and health needs of the population ${ }^{(20)}$.

Hence, the autonomy of the nurse is more apparent in the ESF, through the action of disease prevention and the promotion of health, such as educational activities. These all enable more independence, both in planning and performing the caring activities, and consequently, the effectiveness of care management.

\section{CONCLUSION}

This research identified the main concerns and the main facilities to performance of the actions in care management by the nurse, or in other words, the intervening factors in the performance of the activities of direct and indirect care in an articulated and integrated way in the ESF.

These results demonstrate that Basic Care is an environment filled with ambivalence. On one side it is possible to create an interface between the two dimensions of the work process, from the moment when there are conditions of continuity and execution of the planned activities; on the other side, ESF presents obstacles to achieving the integrality and complementarity between care and management by promoting the division of the activities, especially due to the precariousness of the work process and the emphasis on a traditional assistive model.

We also highlight the conjecture that care management by the nurse is facilitated from support and from the offering of minimal working conditions, by the presence of managers of the AVISA, who provide support in acquiring material, repairing equipment, organizing an adequate work shift and assisting in the instructions as part of the permanent education program. A manager who is nearby that will help to organize the work of ESF teams will empower cooperation among the members of the team and the autonomy of the nurse to manage health promotion activities.

Meanwhile, the inadequate working conditions, as observed by the lack of infrastructure and of minimal teams, harm the performance of activities such as home care and health education. Furthermore, there is also the influence of the curative and medicalized model on the perceptions of the community that the promotion of health is not valued and recognized by the users.

It is important to highlight that the results obtained in this investigation have limitations. As it was done in the ESF of a single municipality it cannot be generalized to the other services provided in Basic Care nationwide, because it is based on the actual health services of the specific population and the dynamic of the work process of nurses in each parcel of the territory.

Moreover, this study does not intend to answer all questions presented and discussed in this article. We want to draw attention and to raise awareness of new discussions about care management by nurses in the ESF, with a special emphasis on the horizontality and aggregation of technologies in relationships and co-responsibility for the actions in health, generating a more ethical, humane and integral care. 


\section{REFERENCES}

1. Christovam BP, Porto IS, Oliveira DC. Gerência do cuidado de enfermagem em cenários hospitalares: a construção de um conceito. Rev esc enferm USP [Internet]. 2012 June [cited 2012 Oct 20];

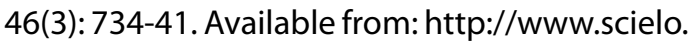
$\mathrm{br} / \mathrm{scielo}$.php? script=sci_arttext\&pid=S0080$-62342012000300028 \& \operatorname{lng}=e n \& n r m=i s o$

2. Fernandes MC, Silva LMS. Gerência do cuidado do enfermeiro na estratégia saúde da família: revisão integrativa. Rev Rene [Internet]. 2013 [cited 2013 Aug 10]; 14(2):438-47. Available from: http://www.revistarene.ufc.br/revista/index.php/ revista/article/view/42

3. Felli VEA, Peduzzi M. O trabalho gerencial em enfermagem. In: Kurcgant $\mathrm{P}$, coordenadora. Gerenciamento em enfermagem. Rio de Janeiro: Guanabara Koogan; 2010.

4. Backes DS, Erdmann AL, Lunardi VL, Lunardi WD, Erdmann RH. Despertando novas abordagens para a gerência do cuidado de enfermagem: estudo qualitativo. Online braz $\mathrm{j}$ nurs [Internet]. 2009 [cited 2012 Oct 20]; 8(2): [about 5 p.]. Available from: http:// http://www. objnursing.uff.br/index.php/nursing/article/ view/j.1676-4285.2009.2407/527

5. Santos JLG, Lima MADS, Klock P, Erdmann AL. Conceptions of nurses on management of care in an emergency department-descriptive exploratory study. Online braz j nurs [Internet]. 2012 Apr [Cited 2012 May 14]; 11(1): 101-14. Available from: http://www.objnursing.uff.br/index.php/ nursing/article/view/3580

6. Hausmann M, Peduzzi M. Articulação entre as dimensões gerencial e assistencial do processo de trabalho do enfermeiro. Texto \& contexto enferm [Internet]. 2009 [cited 2012 Oct 20]; 18(2):258-65. Available from: http://www.scielo.br/pdf/tce/ v18n2/08.pdf

7. Lefèvre $F$, Lefèvre $A M C$. $O$ discurso do sujeito coletivo: um novo enfoque em pesquisa qualitativa (desdobramentos). 2.ed. Caxias do Sul: Educs; 2005.

8. Ministério da Saúde (Brasil). Portaria nº. 2.488, de 21 de outubro de 2011. Aprova a Política Nacional de Atenção Básica, estabelecendo a revisão de diretrizes e normas para a organização da Atenção Básica, para a Estratégia Saúde da Família (ESF) e o Programa de Agentes Comunitários de Saúde (PACS). Diário Oficial da União 24 out 2011. Seção 1.

9. Souza ECF, Vilar RLA, Rocha NSPD, Uchoa AC, Rocha PM. Acesso e acolhimento na atenção básica: uma análise da percepção dos usuários e profissionais de saúde. Cad. saúde pública [Internet]. 2008 [cited 2013 Aug 10]; 24 Suppl 1: 100-10. Available from: http://www.scielo. $\mathrm{br} /$ scielo.php?script=sci_arttext $\&$ pid $=$ S0102$-311 \times 2008001300015$

10. Medeiros CRG, Junqueira AGW, Schwingel G, Carreno I, Jungles LAP, Saldanha OMFL. A rotatividade de enfermeiros e médicos: um impasse na implementação da estratégia de saúde da família. Ciênc saúde coletiva [Internet]. 2010 [cited 2012 Oct 20]; 15 Suppl 1: 1521-31. Available from: http://www.scielo.br/scielo.php?script=sci_artt ext\&pid=S1413-81232010000700064

11. Ceolin T, Heck RM, Pereira DB, Martins AR, Coimbra VCC, Silveira DSS. A inserção das terapias complementares no sistema único de saúde visando o cuidado integral na assistência. Enferm glob [Internet]. 2009 June [cited 2013 Aug 10]; (16):[available from 9 p.]. Available from: http://scielo.isciii.es/ scielo.php?script=sci_arttext\&pid=S1695$-61412009000200017 \&$ Ing =es

12. Franco TB, Merhy EE. Programa de Saúde da Família (PSF): contradições de um programa destinado à mudança do modelo tecnoassistencial. In: Merhy EE, Magalhães Júnior HM, Rimoli J, Franco TB, BuenoWS, organizadores. O trabalho em saúde: olhando e experienciando o SUS no cotidiano: o debate no campo da saúde coletiva. 4. ed. São Paulo: Hucitec; 2007. p. 55-124.

13. Ministério da Saúde (Brasil). Secretaria de Atenção à Saúde. Manual de estrutura física das unidades básicas de saúde: saúde da família. 2. ed. Brasília: Ministério da Saúde; 2008.

14. Ximenes NFRG, Sampaio JJC. Processo de ascenção ao cargo e as facilidades e dificuldades no gerenciamento do território na Estratégia Saúde da Família. Rev bras enferm [Internet]. 2008 [cited 2012 Oct 20]; 61 (1):36-45. Available from: http:// www.scielo.br/pdf/reben/v61n1/06.pdf 
15. Moura BLA, Cunha RC, Fonseca ACF, Aquino R, Medina MG, Vilasbôas ALQ et al. Atenção primária à saúde: estrutura das unidades como componente da atenção à saúde. Rev bras saúde matern infant [Internet]. 2010 Nov [cited 2013 Aug 10]; 10 Suppl 1:69-81. Available from: http://www.scielo. br/scielo.php?script=sci_arttext\&pid=S1519$-38292010000500007 \&$ lng $=$ en

16. Azzolin GMC, Peduzzi M. Processo de trabaIho gerencial e processo de enfermagem na perspectiva de docentes de enfermagem. Rev gaúcha enferm [Internet]. 2007 Dec [cited 2012 Oct 20]; 28(4): 549-55. Available from: http://seer. ufrgs.br/RevistaGauchadeEnfermagem/article/ view/3151/1724

17. Faustino AM, Jesus CAC, Reis PED, Moura EF, Medeiros KC, Amorim MAN. Models management of nursing care: qualitative study. Online brazj nurs [Internet]. 2010 May [Cited 2012 Apr 28]; 9(1): [about 7 p.]. Available from: http://www.objnursing.uff.br/index.php/nursing/article/view/2843

18. Ferreira MEV, Schimith MD, Caceres NC. Necessidades de capacitação e aperfeiçoamento dos profissionais de equipes de saúde da família da $4^{a}$ Coordenadoria Regional de Saúde do Estado do Rio Grande do Sul. Ciênc saúde coletiva [Internet]. 2010 Aug [cited 2013 Aug 10]; 15(5). 2611-20. Available from: http://www.scielo.br/scielo.php?pid=S1413$-81232010000500035 \&$ script=sci_arttext

19. Pavoni DS, Medeiros CRG. Processos de trabalho na equipe estratégia de saúde da família. Rev bras enferm [Internet]. 2009 Apr [Cited 2012 Apr 28]; 62(2): 265-71. Available from: http:// www.scielo.br/scielo.php?script=sci_arttext\&pi $\mathrm{d}=$ S0034-71672009000200015

20. Costa RKS, Miranda FAN. O enfermeiro e a estratégia saúde da família: contribuições para a mudança do modelo assistencial. Rev RENE [Internet]. 2008 [cited 2013 Aug 10]; 9(2): 120-28. Available from: http://www.revistarene.ufc.br/ revista/index.php/revista/article/view/570/pdf

Received: $24 / 10 / 2012$

Revised: $15 / 05 / 2013$

Approved: 22/08/2013 